\title{
Why has the Brazilian economy stagnated in the 2010s? A Minskyan analysis of the behavior of non-financial companies in a financialized economy
}

\author{
Eduardo Mantoan ${ }^{1}$ D $\cdot$ Vinícius Centeno $^{1} \cdot$ Carmem Feijo $^{2,3} \cdot$ Financialization \\ and Development Study Group (FINDE/UFF)
}

Received: 8 December 2020 / Accepted: 10 September 2021 / Published online: 29 September 2021

(c) European Association for Evolutionary Political Economy 2021

\begin{abstract}
The Brazilian economy entered a deep recession in 2015-2016 and since then has shown a sluggish recovery. In this paper, we offer an interpretation for the slow growth based on Minsky's financial instability hypothesis and recent literature on financialization and growth. We analyze the balance sheet of large non-financial companies over the period 2012-2019, a period that comprises the positive investment cycle-initiated during the commodities boom which lasted from the second half of the 2000s until 2014-the 2015-2016 recession, and the period preceding the shock of the COVID-19 pandemic. Based on Minsky's taxonomy of financial profiles, we map a proxy for financial instability at the firm level based on Davis et al. (2019). We also propose an aggregate financial stability index. We conclude that after the 2015-2016 recession, companies have been restructuring their debt profile and adopting a defensive behavior, increasing their liquidity preference. Our analysis supports the interpretation that, even with the sharp fall in domestic real interest rates, the degree of confidence on expectations to recover investment in productive assets is low. This corroborates with the thesis that agents' decisions do not respond only to supply stimulus, but are guided by expectations of future returns, which fundamentally depend on the performance of aggregate demand. Since 2015, Brazilian economic policy has been driven by fiscal consolidation, which has proven ineffective in increasing economic growth.
\end{abstract}

Keywords Financial instability $\cdot$ Minskyan cycles $\cdot$ Financialization $\cdot$ Non-financial companies · Brazil

This paper benefitted from the helpful comments of two anonymous referees from the REPE. Any remaining errors are of the authors' responsibility.

Eduardo Mantoan

eduardo.mantoan@hotmail.com

Extended author information available on the last page of the article 


\section{Introduction}

The literature on endogenous business cycles developed by Minsky points out that an economy that shows a predominance of firms with fragile balance sheets is more exposed and vulnerable to shocks arising from both the goods and services markets, as well as the financial markets. Balance sheet fragility arises because decisions at the firm level are made based on expectations about uncertain returns which, if negative, may lead to an unexpected increase in indebtedness. As long as the financial system is willing to provide credit, firms will be able to meet their financial commitments, albeit becoming increasingly dependent on borrowing new capital and on the uncertainty of the markets. Thus, a reversal in expectations, where a significant number of firms present high financial instability, triggers the downward phase of an economic cycle. Moreover, in a context of a financially integrated economy, business cycles tend to be more severe, and the recovery is slower. ${ }^{1}$

Over the last decade, but especially from 2015 on, Brazil has experienced deep changes in its macroeconomic conditions, leading to a serious recession (2015-2016) and a slow recovery (2017-2019). With that in mind, this paper aims to measure the degree of financial fragility of publicly traded non-financial firms in Brazil between 2012 and 2019, as this period encompasses the deceleration of the positive investment cycle that had begun during the commodities boom in the mid2000s, as well as the recession of 2015-2016 and the period preceding the shock due to the COVID-19 pandemic.

The empirical literature on the financial fragility of firms is relatively scarce in Brazil due to the difficulty in accessing a long and consistent database on firms' balance sheets. A recent work that discusses financial fragility according to Minsky's hypothesis is Feijo et al. (2020); using panel data from the Annual Industrial Survey, the authors developed an analysis of the recent investment cycle in Brazil (2007-2017), arguing that the 2008 international financial crisis hit the Brazilian economy in the ascending phase of a typical Minskyan cycle. They conclude that the deceleration of aggregate demand in the 2010s played an important role in increasing the financial fragility of industrial firms. Meyer and de Paula (2021) also discuss the financial fragility of non-financial firms for the same period using the Economática database. ${ }^{2}$ The authors identify that financially fragile firms in the face of corporate management policies aimed at maximizing the shareholder inhibit productive investments.

\footnotetext{
1 Arestis and Sawyer (2005: 24) present a large survey on financial liberalization and growth. The authors conclude, among other things, that "the analysis suggests that the threats to growth and employment emanating from the financial sector, which Minsky (1986) identified in a closed economy setting, are greatly intensified in open, liberalized economies. Financial liberalization is demonstrated to be a key factor in the process." See also Arestis and Glickman (2002: 244-5).

2 The Economática database collects the balance sheet of the USA and Latin American firms since 1986. Although very large, this database presents gaps and discontinuities regarding Brazilian companies. In this paper, we explore a different database to discuss the financial fragility of non-financial firms, which has not yet been used for this application, as far as our knowledge.
} 
Capital markets are still incipient in Latin America, which means that corporate governance and the usual features of financialized companies are not widespread practices. ${ }^{3}$ Gottschalk and Torija-Zane's (2017) research is relevant reference concerning investigating investment behavior and financialization in non-financial corporations in Brazil. The authors look into the behavior of Brazilian listed corporations focusing on the 2008-2015 period to evaluate to what extent and in which ways financialized practices have taken hold among Brazil's large corporations (p. 162). The authors conclude by the predominance of macroeconomic developments in explaining the slowdown in corporate investments after 2010. Also, the authors report a greater indebtedness of Brazilian non-financial companies after the global financial crisis, although investments in immobilized capital had decelerated. In the authors' words (p. 185), "Brazil's path towards long-term sustainable economic growth depends on a dynamic corporate sector that invests strategically and innovates. Financialization practices in themselves are not a crucial inhibiting factor for unlocking investment and innovation by Brazilian corporations, although in conjunction with other factors, they may become an obstacle as well if they increase financial volatility."

Pushing forward the agenda on financialization and financial fragility of nonfinancial corporations in Brazil, the present paper sheds light on how non-financial companies faced the 2015-2016 recession. The data of consolidated financial statements were obtained from the Brazilian Securities and Exchange Commission $(\mathrm{CVM}) .{ }^{4}$ We show that non-financial companies were highly leveraged in the prerecession period and chose to prioritize the restructuring of their balance sheets and debt profile in the post-crisis. To do so, large non-financial companies deepened their financialization practices. Therefore, the building up financialization practices during the recent recessive period, on the one hand, combined with the weak recovery of aggregate demand following austerity fiscal policy on the other, help to explain the slow recovery of the Brazilian economy in the second half of the 2010s. Although the analysis focuses on the Brazilian case, we believe that the recent Brazilian experience can be taken as a good example of the failure of austerity policies and liberal reforms in financialized economies to overcome a downward phase of the business cycle. In the case of Brazil, austerity policies and liberal reforms, instead of recovering the confidence of both domestic and international private investors, have induced large firms to postpone long-term investments, and therefore, depressing aggregate gross capital formation.

In order to analyze the macroeconomic implications of the financial instability of non-financial companies, the remainder of this paper is divided into four sections. Section 2 revisits the literature on the phenomenon of financialization and its connections to the economic cycle. Section 3 presents some insights on Brazil's economic performance in the 2010s. Section 4 proposes a financial instability proxy for 100 publicly traded non-financial Brazilian companies and an aggregate financial

\footnotetext{
3 See Torija-Zane and Gottschalk (2018).

4 The database may be accessed through the following address: http://dados.cvm.gov.br/dataset/cia_ aberta-doc-itr.
} 
stability index that, together with the analysis of the liabilities and cash flow structures, allows us to understand the reasons for the slow recovery after the 2015-2016 recession. Lastly, Section 5 offers the final considerations.

\section{Minsky's financial instability hypothesis and the financialization of modern economies}

Minsky's work stands out for its explanation on the cyclical and organically unstable behavior of monetary economies with sophisticated financial systems. Owing to the interaction between the real and the monetary sectors, economic crises almost always tend to manifest themselves in the financial sector, emerging from the monetary contractual commitments between economic agents (Minsky 1981).

Contemporary debates in macroeconomics, especially after the great financial crisis of 2008, focus on the financialization process as a new accumulation regime, in which productive activities are subordinated to finance. ${ }^{5}$ The financialization process of modern economies implies a regime in which the monetary and financial flows are the main sources of income generation, instead of the productive allocation of resources. ${ }^{6}$ Aglietta (2000) explains that this logic emerges out a systemic lack of aggregate demand, and therefore, the financialization process creates a selffulfilling virtuous cycle by changing the behavior of non-financial firms towards the maximization of shareholder value. ${ }^{7}$ When the financial logic becomes dominant, the pattern of corporate governance tends to increase a company's level of indebtedness (Orhangazi 2008; Mazzucato and Wray 2015). This increases the weight of liabilities in the balance sheet, which makes the company more exposed to the changes in the financial conditions and consequently weakening its balance sheets. ${ }^{8}$ From a macro point of view, in a financialized economy, firms can indefinitely postpone their investment projects with longer payback periods. ${ }^{9}$ This results in depressing

\footnotetext{
5 See, for example, Mader et al. (2020). Particularly in developing economies, the financialization process is associated with financial liberalization and the subordinate integration of these economies into the international financial system (see, e.g., Karwowski and Stockhammer 2017).

6 According to Palley (2013), the main impacts are related to the greater significance of the role of the financial sector in comparison to the productive sector, to the transfer of income from the real sector to the financial sector, and also to the increase in income inequality and stagnation. In this environment, it is expected that non-operating income represents a greater share in the composition of total profit, since companies can compensate a fall in their investments in core activities by increasing financial revenue.

7 For Aglietta (2000), maximizing shareholder value is the norm of financialized capitalism. In other words, the adoption of administrative and financial corporate governance strategies that induce the firm to maximize shareholder wealth becomes the main purpose of the company.

8 Palley (2013) adds that there were clear indications that financialization raised the financial instability of the US economy, and that the financial crisis in 2008 reinforced this view.

9 Under high uncertainty and cash restriction, companies tend to prioritize short term return investments, such as financial applications (Hein and Van Treeck 2008). Guttmann (2017) understands that the financial boom contributed to an industrial stagnation, directing a large volume of resources from fixed assets, i.e., productive investments, to short-term speculation. The author adds that financial assets are inherently attractive not only for their liquidity but also for their mobility. For a critical analysis regarding industrial stagnation and the financialization of NFC, see Davis and McCormack (2021).
} 
aggregate demand, which shortens the duration of the economy's expansion cycles, making the economy more volatile. ${ }^{10}$

Minsky's financial instability hypothesis (FIH) (Minsky 1992) states that periods of expansion are followed by periods of instability (booms and busts), with the latter being generated endogenously during the stable phase of the cycle. ${ }^{11}$ Minsky's (1992) FIH stems from Keynes's investment determination theory. The fundamental ideas are the confidence in expectations and conventions, introduced by Keynes (1936, chap.12). Keynes's investment theory is developed assuming that expectations about future returns are uncertain because the future is unknowable. Given that expectations are shaped under uncertainty, the important factor to determine the investment decision in fixed assets of private agents concerns their state of confidence-built up by the business environment and economic policy conventions. In other words, a successful economic policy is that which is able to anchor the expectations of private agents by creating the context to stimulate productive investment decisions, which will be consolidated when the necessary conditions to sustain effective demand are established.

Thus, the realization of cash flows today relies on the expected returns in the past that have induced investment decisions. Economic units need to generate income in the present to settle debts incurred in the past, and at the macroeconomic level, this implies that aggregate demand must be expanding. ${ }^{12}$ The realization of future demand arises from the implementation of investment plans in the present, which, in turn, depends fundamentally on the agents' future expectations. In this sense, investment is, for Keynes (1936), the key macroeconomic variable to keep the economy in an expanding trajectory. This allows agents to fulfill their expectations. However, both lenders and borrowers make their decisions under non-probabilistic uncertainty, and for this reason, investment presents itself as a volatile variable, since different agents assume different risk positions over time.

By integrating the financial determinants of investment decisions into Keynes's investment theory, Minsky (1986) shows how the structure of liabilities inherited from past decisions should be met by the generation of cash flows in the present. Debt commitments taken in the past represent a certain future cash outflow, while future inflows are expected-but they may or may not happen. Ideally, if initial expectations are fulfilled, firms will be able to maintain the cash inflow according to payment flow. The macroeconomic context plays an important role in the development of the business cycle, as the confidence in past decisions stimulates firms and financial institutions to move on to higher risk decisions. In a financialized context, one should consider also the degree of financialization of the firm. When the maximization of the shareholder value

\footnotetext{
10 Additionally, Kohler et al. (2019) identify that the financialization at firm level has contributed, through various channels, to reducing the share of wages in the functional distribution of income.

11 In this article, we work with this definition of cycle. For a survey of different models of Minskyinspired economic cycles, see Nikolaidi and Stockhammer (2017).

12 Minsky (1978, p. 92) points out that "profits are that part of prices that supports the financial system and the structure of financial relations by providing the cash flows that validate past financial commitments".
} 
guides corporate finance decisions, the obligation to pay high dividends to shareholders, for instance, might delay the recuperation on long-term investment.

It is precisely in the ascending phase of the cycle and greater apparent stability of the economy that agents take greater risks, since there is optimism and confidence regarding future returns. As long as positive expectations persist, companies assume speculative positions. That is, they choose to roll over the debt by contracting new loans to amortize the principal amount. In spite of not being perceived at the time of borrowing, as more companies take on greater risk, this behavior enhances financial instability since the safety margins are being reduced. The increase in risk is only perceived later, when, for example, the monetary authorities raise the interest rate to contain inflationary expectations and a fall in aggregate demand reverses the state of expectations. If the recession is widespread, banks quickly reduce credit availability and raise interest rates, increasing the non-financial firm's debt burden and diminishing their ability to negotiate new debts. This movement highlights the pro-cyclical nature of banks' credit supply. The endogeneity of the economic cycle is due to the fact that, like other agents, banks decide under uncertainty and crucially interfere in the allocation of resources by making their own decisions. Uncertainty about the future, therefore, drives the economic choices of private agents. Moreover, it should be considered that in a financialized economy, large firms have more opportunities to sustain positive cash flow supported by financial receipts for a long period, what may contribute to delay the recovery in investment in longterm assets.

Minsky's FIH is built on the understanding of how the dynamics of investment funding take place and on the interaction between non-financial firms and the financial system in market economies. Minsky proposes a taxonomy to classify the degree of financial instability of firms, based on the analysis of the cash inflows and outflows of firms. The well-known profiles are hedge, which is when the expected inflow exceeds the outflow associated with the payment commitments assumed in each period; speculative, which is when the accounting period inflow is not enough to cover the outflow amount, but still sufficient to pay the interest incurred on the principal; and Ponzi, which is when the firm's cash inflow is not enough to cover the principal and interest due to past debt commitments. Ponzi companies are forced to sell assets or take out new loans in the short term to pay interest on the loans. If the economic unit assumes both strategies simultaneously, there is a decrease in its equity assets and an increase in the stock of debt, which reduces the safety margin of creditors (Minsky 1992). There is no other way out, therefore, except to refinance its liabilities. This is what makes Ponzi firms highly dependent on the financing conditions of the financial markets.

The conventional taxonomy proposed by Minsky provides a theoretical apparatus that allows the interpretation of how the business cycle evolves. When an economy emerges from a recession and does not resume growth, as is the current case of the Brazilian economy, one may conclude that agents show a defensive posture by postponing long-term investment decisions. 


\section{Macroeconomic policy and the end of the investment cycle of the Brazilian economy in the 2010s: fall in the investment rate and increase in finance asset flows}

The aim of this section is to briefly discuss the macroeconomic evolution of the Brazilian economy in the 2010s to support our argument that the financial fragility of non-financial firms increased with austerity. As will be seen, the 2010s are marked by a shifting macroeconomic policy, which has spread more uncertainty instead of coordinating expectations that would induce productive investment. When the macroeconomic indicators deteriorated in 2014-2015 (inflation and public debt), an austerity agenda of economic policy was implemented in 2015, aiming at a rapid improvement in public debt and inflation, which did not happen. A deep recession followed, and the perception of increased uncertainty due to the erratic conduct of macroeconomic policy led to defensive behavior by the companies Table 1 shows GDP growth rates and aggregate demand components for selected periods. In the first line are the rates for the period 2008-2010, when GDP grew 4.1\% per year on average. This result shows that the Brazilian economy responded positively to the stimulus of aggregate demand after the impact of the 2008 subprime crisis. The slight decrease of $-0.1 \%$ in 2009 was followed by a surprising expansion of $7.5 \%$ in 2010. In the same period, gross fixed capital formation expanded by an average of $9.0 \%$ per year. As of 2011, the Brazilian economy starts to slow down. Between 2011 and 2014, average growth stood at $2.3 \%$ per year, despite changes in the management of macroeconomic policy that aimed to stimulate the growth rate of gross capital formation, which was substantially reduced (2.2\% per year) compared to the previous 3-year period.

In the period 2011-2014, due to the slowdown in GDP growth, macroeconomic policy initially reacted in the same way as in 2008 by easing monetary and fiscal policies to boost aggregate demand. ${ }^{13}$ With plenty of international liquidity, one of the objectives of easing monetary policy was to induce a depreciation of the nominal exchange rate, which implied reducing the domestic interest rate. ${ }^{14}$ According to Oreiro (2017), the Brazilian Central Bank started to tolerate a higher inflation rate. In fact, the average inflation rate in the period 2011-2014 was around 6.0\%, exceeding the target of $4.5 \%$ per year as established by the inflation targeting regime. Graph 1 shows the evolution of the domestic real interest rate and the real exchange rate, both impacting on the cost of investment in capital formation. Between June 2011 and October 2012, real monthly interest rates declined and the real exchange rate depreciated by around $22 \%$. In November 2012, the downward trend in the real

\footnotetext{
13 According to Barbosa $(2010 ; 1)$ “.... a sequence of unprecedented expansionary actions running from credit expansion to fiscal stimuli to boost aggregate demand and to avoid an excessive accumulation of inventories, especially of consumer durable goods, were well succeeded to recover the economy in 2010." However, as pointed out by Paula et al (2015), the economy started the 2010s in a more fragile situation and the European crisis in 2011-2012 imposed new challenges to the macroeconomic authorities.

14 For an analysis of the role of currency exchange rate, the external sector and the impacts on foreign trade patterns, see Nassif et al. (2020) and Nassif and Castilho (2020).
} 
interest rate was interrupted, and in April 2013, it began to increase again: The real interest rate started at $1.6 \%$ in November 2012 and reached a peak of $6.2 \%$ in September 2015, the first year of GDP contraction. ${ }^{15}$

The government's assessment was that the easing of monetary policy at the beginning of the decade created fiscal space for the reduction of the ratio of primary surplus to GDP needed to stabilize the public debt in relation to GDP. In addition, the slowdown in growth in 2012 (GDP growth of 1.9\%) indicated a fading of aggregate demand and the need for fiscal stimulus. However, the fiscal space was used to promote a round of tax cuts for both the productive sector and consumers, rather than an increase in public investment. Public sector investment went from $4.6 \%$ of GDP in 2010 to $3.9 \%$ in 2014 (Pires 2021), leading to a reversal in the aggregate investment rate from 2014 on (Graph 2, dashed line). The decision to reduce public investment and expand tax exemptions also had negative results on the primary surplus. With the increase in inflation since 2014 and the deterioration of government accounts, with no positive reaction from the economy (GDP growth in 2014 was only $0.5 \%$ ), the government adopted, as of 2015 , a policy of fiscal austerity. The attempt to promote a change in the macroeconomic policy arrangement towards a lower nominal and real interest rate and a more competitive real exchange rate was abandoned, and the Brazilian economy plunged into a deep recession in 2015 and 2016 (a contraction of $3.4 \%$ per year in GDP). As can be seen, the sluggish growth in the triennium 2017-2019 has not yet recovered the GDP level of the beginning of the decade.

Graph 2 shows the evolution of the rate of investment in fixed capital in the present decade and an aggregate financial investment proxy (the ratio between the accumulation of financial assets and the total investment flow in financial and fixed assets). The result illustrates well how expectations regarding future returns on investment in fixed assets changed as of 2014 with the cut in public investments and increased uncertainty about sustaining aggregate demand. Demand for financial assets, on the other hand, gains weight in the total flow of investments in line with the slowdown in investment in fixed assets, pointing to a defensive posture on the part of economic agents, in particular non-financial companies.

As seen in the previous section, non-financial companies finance their investments through funding in the financial market based on a positive expectation of future returns. As the macroeconomic scenario did not improve with austerity policies and liberal reforms that follow in 2016 (labor market liberalization), expectations on long-term growth did not recover, leading firms to cut investment and contributing to contracting aggregate demand. A possible interpretation for the deceleration of the investment and the increase in the financial fragility of non-financial firms in the Brazilian case in the post-recession period of 2015-2016, therefore, considers that only reducing interest rates from 2016 onwards (Graph 1) had not been enough to

\footnotetext{
${ }^{15}$ For a critical review of the macroeconomic policies adopted in Brazil in the 2000s and 2010s, see, for instance, Serrano and Summa (2015), Ferrari et al. (2014), Oreiro and D'Agostini (2017), and Carneiro (2017).
} 
Table 1 GDP growth rates and aggregate demand components: selected periods - \%

\begin{tabular}{lcccccc}
\hline & GDP & $\begin{array}{c}\text { Household } \\
\text { consumption }\end{array}$ & $\begin{array}{c}\text { Government } \\
\text { consumption }\end{array}$ & $\begin{array}{l}\text { Gross fixed capi- } \\
\text { tal formation }\end{array}$ & Exports & Imports \\
\hline $2008-2010$ & 4.1 & 5.7 & 3.0 & 9.0 & 0.6 & 13.1 \\
$2011-2014$ & 2.3 & 3.5 & 1.7 & 2.2 & 1.4 & 3.6 \\
$2015-2016$ & -3.4 & -3.5 & -0.6 & -13.0 & 3.8 & -12.3 \\
$2017-2019$ & 1.3 & 2.0 & -0.2 & 1.2 & 2.1 & 5.3 \\
$2008-2019$ & 1.5 & 2.5 & 1.1 & 0.8 & 1.8 & 3.4 \\
\hline
\end{tabular}

Data source: Brazilian Statistical Office Quarterly Annual Accounts

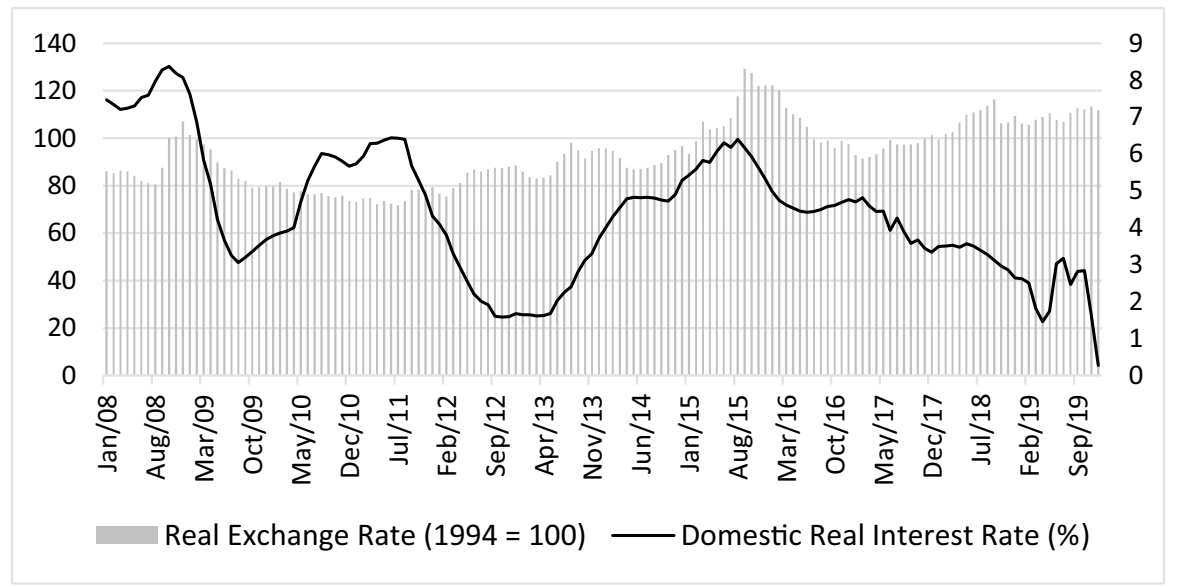

Graph 1 Domestic real interest rate (\%) and the real exchange rate (index): 2008-2019. Data source: the Brazilian Central Bank for the real effective exchange rate (series 11,752) and for domestic real interest rate (series 4189 deflated by the inflation rate accumulated in 12 months)

induce the resumption of private investment. As will be seen in the next section, the decision of large companies was to revise their balance sheets.

\section{The recent investment cycle of the Brazilian economy and Minsky's hypothesis of financial instability: analysis of a sample of publicly traded non-financial companies}

Following Minsky's taxonomy, this section presents an analysis of 100 publicly traded non-financial companies in Brazil between 2012 and 2019. The sample comprehends the top 100 companies publicly traded in Brazil by market value ranking. As of CVM Instruction No. 480/2009, articles 21 and 29, publicly traded companies were required to periodically submit the Quarterly Information Form (ITR) filled with the financial statements data only from 2010 onwards. The Commission has made these data available, offering a completer and more homogeneous sample. For 


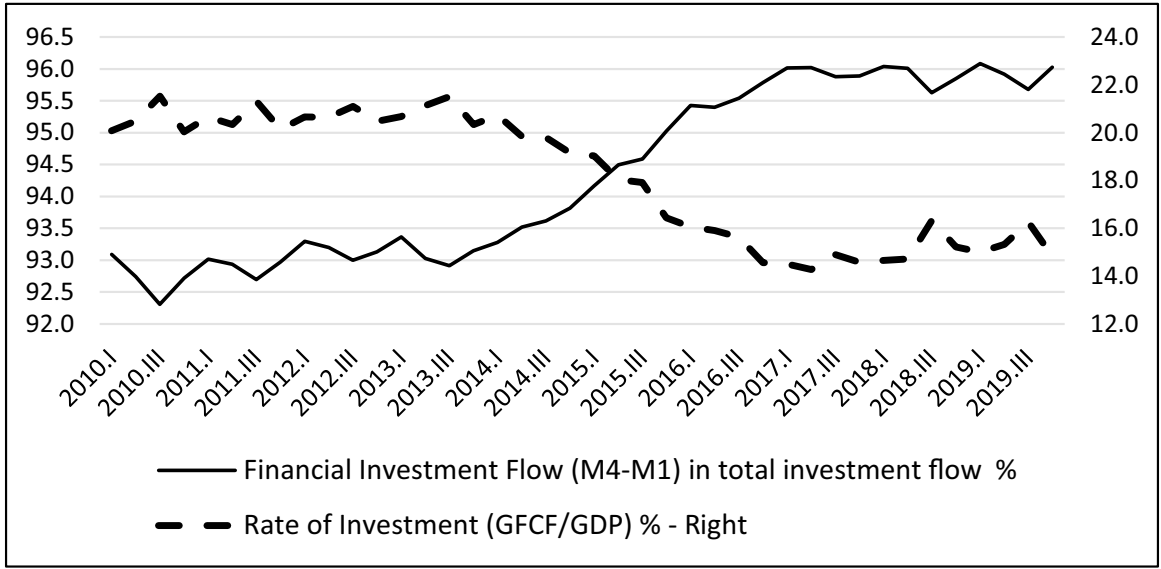

Graph 2 Rate of investment (\%) and financial investment flow (\%): 2010-2019. Data source: Brazilian Central Bank (series 27,791 and 27,815), where aggregate investment includes both private and public sectors investment; Brazilian Statistical Office Quarterly Annual Accounts

this reason, we opted to use the CVM database. Companies whose data was available for a period inferior than 4 years were skipped. It is important to highlight the low level of development of the capital market in Brazil when compared to developed countries (total number of non-financial listed companies was 347 in 2019), which implies greater difficulty in obtaining adequate data. Brazilian firm-level data are in many cases incomplete and heterogeneous or have a short time series.

To distinguish between the financial profiles, we use a definition based on Davis et al. (2019), a study in which the authors calculate the relationship between cash inflows (source of funds) and outflows (cash commitments) for a sample of US nonfinancial firms. ${ }^{16}$ Like Davis et al. (2019), we assume that non-financial companies in a hedge situation are those that presented an inflow higher than the outflow, sufficient to settle all their financial commitments. Companies in a speculative situation are those that did not show sufficient inflow to fully cover the outflow, but sufficient to bear the interest and charges expense. And finally, the companies with a Ponzi profile are the ones that did not generate enough cash to pay neither the interest and taxes nor the amortization of the principal.

We represent the cash inflow $(\pi)$ as the sum of the firm's operating profit before the financial result (OpPro) and financial income $(F I)^{17}$ :

$$
\text { Cash Inflow }=\pi=\text { OpPro }+F I
$$

\footnotetext{
16 For details on the accounting items that comprise cash inflows and outflows, see Table 2 in Davis et al. (2019, p. 6). See also Caldentey et al. (2019, p.18-19, Table 9), which summarizes different methodologies to calculate Minsky's typology.

17 In line with Brazilian accounting standards, the entry of financial income must include gains from financial investments, interest income, and discounts.
} 
The cash outflow $(O)$ is defined as the sum of the payment of interest and other financial expenses-except currency exchange variations- $(F E)$, payments of income tax and social contribution on profit $(T)$ and amortization of loans, financing, and debentures $(A)$ :

$$
\text { Cash Outflow }=O=F E+T+A
$$

The proxy for non-financial companies' financial instability is calculated as an index as:

$$
F F=\frac{\pi-(F E+T)}{A}
$$

If $\pi \geq \mathrm{O}, \pi-(\mathrm{FE}+\mathrm{T}) \geq \mathrm{A}, F F \geq 1$, the company presents a hedge profile.

If $\pi<\mathrm{O}, \pi \geq \mathrm{FE}+\mathrm{T}, \pi-(\mathrm{FE}+\mathrm{T})<\mathrm{A}, 0<F F<1$, the company is classified as speculative.

If $\pi<\mathrm{FE}+\mathrm{T}, \pi-(\mathrm{FE}+\mathrm{T})<0, F F<0$, the company presents a Ponzi profile.

In addition to classifying the financial profile of non-financial companies, we calculated an aggregate index for financial stability. According to Minsky (1986, p. 232), the number of hedge, speculative, and Ponzi finance units is one of the main determinants of economic stability. The author adds that the greater the weight of companies in speculative and Ponzi positions, the lower the safety margins of the economy and the more fragile the financial structure. For this reason, the construction of the weighted aggregate financial stability index (AFFI) aims to capture the predominance of a certain profile over the period observed in the sample ${ }^{18}$ :

$$
\mathrm{AFFI}_{t}=\frac{\left(0 \times \sum_{i=1}^{j} C_{i t}^{\text {Ponzi }}+50 \times \sum_{i=j+1}^{k} C_{i t}^{\text {Speculative }}+100 \times \sum_{i=k+1}^{n} C_{i t}^{\text {Hedge }}\right)}{\sum_{i=1}^{n} E_{i}} \times 100
$$

The AFFI consists of multiplying the sum of companies by profile $(C)$ as follows: by 0 (Ponzi profile), by 50 (speculative profile), and by 100 (hedge profile). The weighted sum is divided by the total number of companies in the sample. Since we multiply the result by 100 , the index varies from 0 to 100 .If all companies were in a Ponzi position, the index would be zero, whereas if all were in a hedge position, the index would be 100 . A result equal to 50 would indicate that all companies are in a speculative situation. Therefore, we define the following intervals:

$$
\begin{aligned}
& 0<\mathrm{AFFI}<50 \rightarrow \text { Speculative-Ponzi predominance } \\
& 50<\mathrm{AFFI}<100 \rightarrow \text { Speculative-Hedge predominance }
\end{aligned}
$$

\footnotetext{
18 The construction of the index followed a proposal similar to that developed in Torres Filho et al. (2019).
} 


\section{Results}

The empirical analysis indicates that there was a process of significant restructuring of the financial profile of the companies between the years 2012 and 2019. Graph $3^{19}$ shows that from 2015, over $50 \%$ of the larger non-financial Brazilian firms were in a speculative and Ponzi position. ${ }^{20}$ According to the data displayed on IMF Datamapper - Global Debt database, the indebtedness of the NFC sector in Brazil was about $43.8 \%$ of GDP in 2019. The indebtedness of the companies included in the sample equals to $14.7 \%$ of GDP in the same year. This means that the volume of debt of the companies in the sample represents approximately $34 \%$ of the total indebtedness of the aggregate of all non-financial companies in the Brazilian economy, which indicates the representativeness of the sample.

The changes in the relative percentage of profiles between 2012 and 2019 are linked to the impacts of the economic crisis that hit Brazil in 2015-2016. In 2016, $15 \%$ of the largest non-financial companies in the sample were in a Ponzi position. If we consider only the inflow of operating profits (excluding financial income) to calculate the financial posture of the firms, more than half of them in 2015 (52\%) and in 2016 (59\%) were in the Ponzi category. According to Carvalho (2018), the close relationship between financial capital and productive capital has its expression in Brazil marked by the greater importance of firms' treasury investments. Thus, the thesis that financial revenues gain greater prominence in financialized economies is reinforced. $^{21}$

Furthermore, Graph 3 shows that the scenario started to reverse from 2017 onwards, with a reduction of non-financial companies in the Ponzi situation. The improvement in the financial profile of companies as of 2017 was mainly driven by the slight increase in their operating profits in the period, which, coupled with the mitigation of financial expenses, ${ }^{22}$ allowed part of the companies to slowly restructure their cash flow after the 2015-2016 recession. The evolution of the weighted aggregate financial stability index (AFFI) is shown in Graph 4, considering two definitions of the AFFI: (a) AFFI considering the cash inflow as defined considering $(\pi)$ and (b) "AFFI excluding FI", that is, considering the operating profit only.

Looking at the entire series, the AFFI indicates that the large non-financial companies had a predominance of speculative-hedge profiles. From the sample used in this paper, the analysis does not take into account the firms' classification by size

\footnotetext{
${ }^{19}$ Companies with missing data for any year and those that perhaps did not declare the amount of loan repayments were excluded, since the absence of these data makes the proxy calculation impossible.

20 Data on "Nonfinancial corporate debt, loans and debt securities" as a percentage of GDP are available at: https://www.imf.org/external/datamapper/NFC_LS@GDD/BRA.

21 The historically high real interest rates were the incentive for companies to use cash surpluses to invest in financial assets (mainly government bonds), which are quasi-currency and provide high shortterm yield (Carvalho 2018). Therefore, there is no tradeoff between risk, liquidity, and return.

22 The sharp movement to reduce the basic interest rate started in late 2016, more specifically on November 30, 2016, when COPOM (Monetary Policy Committee) reduced the Selic target from 14 to $13.75 \%$. By December 31, 2017, the rate had dropped to $7 \%$.
} 


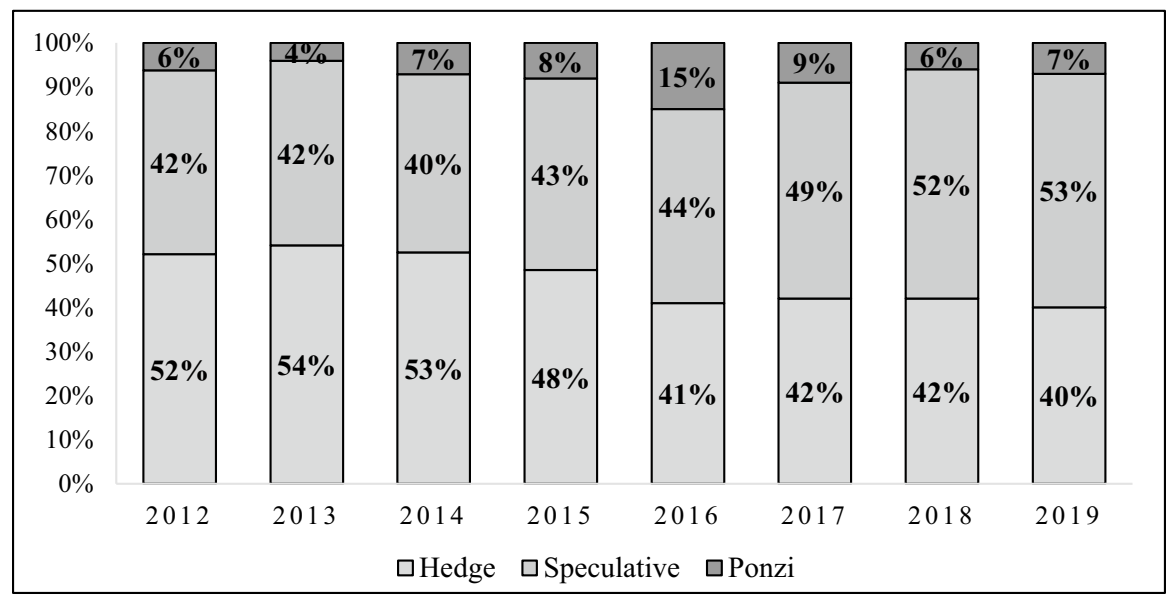

Graph 3 Percentage of non-financial companies by financial profile (2012-2019). Data source: authors own elaboration based on CVM database

or sector. ${ }^{23}$ Regarding this matter, Davis (2016) brings important contributions by identifying different patterns of financialization depending on the size and sector of firms. According to the econometric tests presented in the article, the author points out that deleveraging is one of the stylized facts of financialization in small companies in the USA, mainly due to easier access to working capital. Although there is a difference between the sizes of companies listed B3 - Brazilian stock exchange (especially the huge Petrobras S.A. and Vale S.A.), it is understood that all of them can be considered large. The analysis based on the two proposed scenarios can signal the degree of dependence of firms on their non-operating results to meet their financial obligations. When disregarding financial revenues, a very significant gap is noted. That is, financial revenues contribute to mitigating the financial instability of the economy in the sense of Minsky (1986). ${ }^{24}$

In 2013 is when the AFFI index reached its highest level. In other words, the companies classified as hedge and speculative predominated. This is the moment that, according to Minsky, precedes the cyclical reversal. The index reaches its minimum value in 2016, in line with the increase in the number of companies in the Ponzi situation that year. From 2016 onwards, there has been a process of recovery, indicating a restructuring of the cash flow of companies to reduce financial instability. However, the recovery has not yet allowed the degree of financial stability in the post-2015 crisis period to reach the pre-recession levels.

\footnotetext{
23 Table 2 in the Appendix contains the list of firms and its respective sectors.

24 Minsky (1986, p. 232) describes this as follows: "Whereas hedge finance units are vulnerable to difficulties in fulfilling outstanding financial commitments only if receipts fall short of expectations, speculative and Ponzi-financing units have to meet changing financial-market conditions".
} 


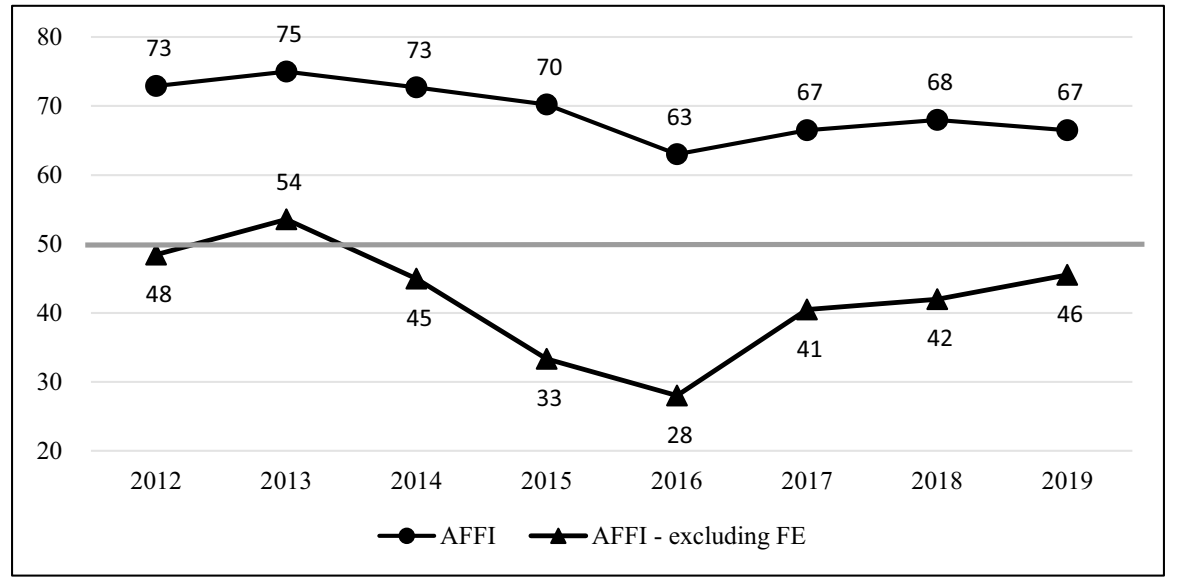

Graph 4 Weighted aggregate financial stability index (AFFI): 2010-2019. Data source: authors own elaboration based on CVM database

Graph 5 shows the evolution of the cash inflow (on the left) and the cash outflow (on the right) for the whole sample of non-financial firms and compares both flows with the AFFI.

The evolution of the AFFI and the operating profit has similar trajectories, with the exception of 2015. Even so, the worsening of the AFFI in 2015 and 2016 is accompanied by a fall in operating profit in 2015. On the other hand, from 2016 on, there is an increase in the amount of amortization paid by non-financial companies. In 2019, the fall in the operating profit and the continued growth in the amortized volume caused a deterioration in the AFFI that year. Regarding financial income, the graph shows that it exceeded operating profit in 2015-2016. There are two reasons for this: (a) the crisis negatively affected the operating profit of companies, and (b) the high interest rates between 2015 and 2016 led to a higher return on financial assets held by the companies.

Thus, the increase in amortization paid since the recession suggests a strategy of restructuring the debt profile in order to alleviate future cash flow commitments. In order to better understand this behavior, the values referring to the volume of new loans and funding from financial institutions were incorporated into the analysis, as well as the volume of new investments and the amount of loans of long-term liabilities. $^{25}$ This is shown in Graph 6.

In 2019, the increase in amortizations in relation to 2018 (8.4\%) was accompanied by greater funding (19.2\%) and a reduction in the loans of long-term liabilities $(-4.2 \%)$, while investment intensified its downward trend (-2.7\%). Graph 6 also shows a sustained downward trajectory in long-term liabilities since the peak of

\footnotetext{
25 Non-current liabilities represent obligations that must be settled after the year following the closing of the current balance sheet. In this paper, we use non-current liabilities as a proxy for long-term debt. The amounts are available in the companies' balance sheet statements.
} 


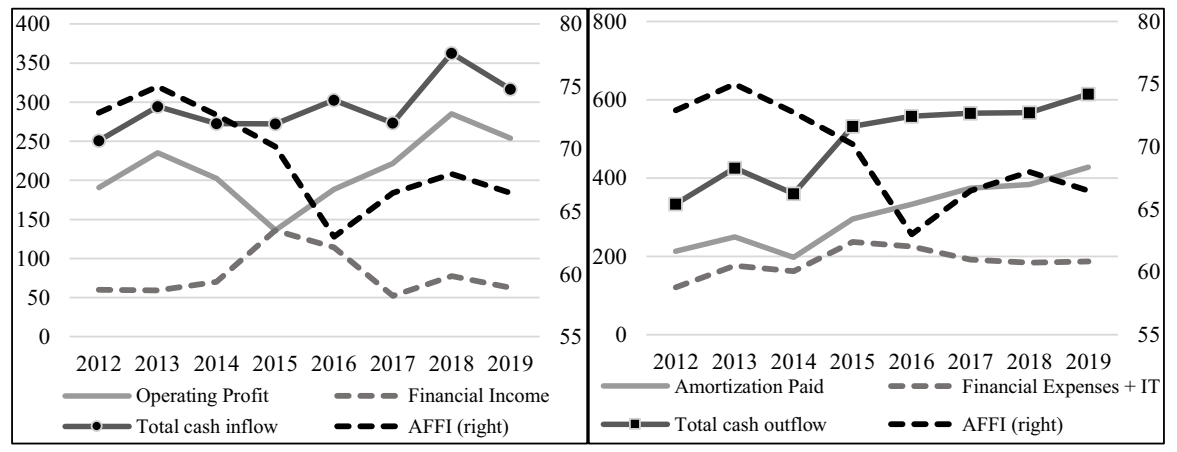

Graph 5 Cash inflow (left) and cash outflow (right) (in billions of R\$): 2012-2019. Data source: authors own elaboration based on CVM database. Values updated by inflation at 2019 prices

the series in 2014. Taken all together, the evolution in the amount of amortization and funding and long-term liabilities points to a restructuring of the debt profile of the non-financial companies. When adding new loans and the level of investment to the analysis, a possible interpretation is that non-financial companies are using the funds raised in order to roll over their past debt and are postponing investment expenditures.

Some hypotheses can be made to interpret the causes of the debt rollover. In 2019, the basic interest rate of the Brazilian economy fell to historical lows, closing the year at $4.5 \%$. The drop in the interest rates opened an opportunity for indebted companies to amortize their old debts contracted at higher interest rates and exchange them for new debt at lower interest rates. Investment in fixed assets, in turn, has fallen successively since 2013. This behavior, combined with the increase in the amortized volume over the years, characterizes the conservative behavior on the part of non-financial companies, indicating that expectations have not been restored since the 2015-2016 recession. In times when expectations are low, supply side policies, such as reducing interest rates $^{26}$ and tax exemptions, prove to be ineffective in promoting the resumption of private investment. The interpretation of the results presented in this paper aligns with the conclusion of report no. 999 from $\operatorname{IEDI}^{27}$ (2020):

With operating profitability contracting, the continuation of the trajectory of expansion of net profit margins reflected, in good measure, the process of rene-

\footnotetext{
${ }^{26}$ In addition to falling interest rates, fiscal austerity and economic reforms were implemented on the assumption that this would boost private investment. The reforms consisted of limiting labor rights, restricting access to unemployment insurance and a set of tax exemptions, as reported by Carvalho (2018), as well as the implementation of an expenses' limiter, known as the "spending ceiling", which is based on the "expansionary fiscal contraction" argument (Paula and Oreiro 2019). However, this agenda failed to boost private investment.

27 The Institute for Industrial Development Studies (IEDI) was created in 1989 and currently brings together 50 entrepreneurs representing large national companies. It is a think tank in industrial analysis in the country.
} 


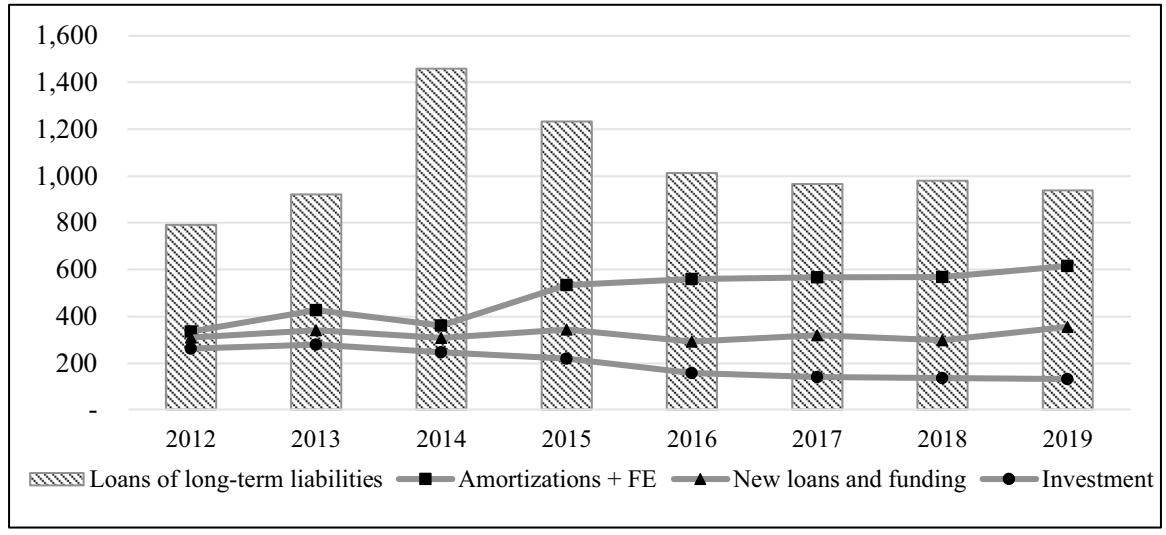

Graph 6 Loans of long-term liabilities, amortizations plus financial expenses, new loans, and funding and investment (in billions of R\$): 2010-2019. Data source: authors own elaboration based on CVM database. Values updated by inflation at 2019 prices

gotiating debts and improving the structure of liabilities (...) The impact of the reduction in interest rates had effect not only on the restructuring of long-term debt, but also on the reduction of working capital costs and other short-term financial expenses. Although the reduction in financial costs also has a positive impact on the opportunity cost of investments, the low demand and the stagnation of profitability at lower levels have been shown to be more relevant factors in investment decisions (free translation).

Another relevant nuance of the interpretation is that, as expectations about the growth prospects of the economy are low, non-financial firms seek refuge in financial applications to sustain their profit, instead of investing in long-term productive investments. ${ }^{28}$ On this subject, Feijo et al. (2016) point out that the dynamics of economic policy in Brazil have not favored long-term investment decisions and, thus, support a vicious cycle of low growth.

According to Stockhammer (2004), the loss of investment priority compared to financial commitments is widely consolidated in the literature on financialization from two main axes: the crowding out effect of productive investment in favor of financial capital accumulation and the orientation of maximizing shareholder value (MSV). The theory of maximizing shareholder value finds that this same mechanism of priorities may also imply the sacrifice of productive investments in order to

\footnotetext{
28 See, for example, Guttmann (2017). The financial explosion fueled an industrial stagnation directing a large volume of resources from investments in fixed assets, that is, productive, to short-term speculation. Such (financial) assets are inherently attractive not only for their liquidity, but also for their mobility. The author calls "financial centralization" the growing importance of financial assets in the balance sheets of non-financial actors, such as families and industrial firms.
} 
distribute dividends to the shareholders. Graph 7 allows us to analyze the behavior of firms' productive investment in comparison to the volume of dividends distributed. ${ }^{29}$

It is worth noting that both variables suffered a shock in the 2015-2016 recession, while only the volume of dividends paid has resumed its growth trajectory. Although the proportion of dividends distributed by companies shows an upward trend in relation to productive investment, the data does not provide enough evidence to corroborate or not the strategy of maximizing shareholder value. ${ }^{30}$ The variation in the dividend's payment is small, while the investment variable takes all the action. Such behavior reinforces the thesis of a defensive and conservative behavior on the part of companies.

In short, it is understood that the dynamics of financialized economies have made financial and economic crises not only more recurrent, but also deeper. Epstein $(2005)^{31}$ offers a broad definition of financialization, where financial links among economic agents are intensified and the degree of overall indebtedness increased. We may suggest that the increased dependence on finance turns the balance sheet of economic agents more fragile in a monetary economy. One consequence is that the recovery of the economy might be slower, given the lower weight of operating income in the composition of firms' revenues and the diverse range of financial assets available, causing the crowding out of productive investment. In short, due to the pro-cyclical and dysfunctional nature of financialization, there is great difficulty in restoring the state of expectations of agents who, when faced with supply side stimuli, prefer to revise their balance sheets and profits, restructuring their debt profile. The response of Brazilian economic policy has been, since 2015, to cut public spending and adopt a fiscal austerity policy agenda. This means it has gone in the opposite direction of sustaining aggregate demand to anchor the expectations of agents in order to stimulate productive investment and, ultimately, promote economic growth.

\section{Concluding remarks}

In this paper, we use the recent experience in Brazil to support our argument that austerity policy measures do not recover business expectations in such a way as to enhance investment decisions in long-term assets. Based on Minsky's financial instability hypothesis, we performed an empirical analysis to identify the financial

\footnotetext{
${ }^{29}$ Dividends are also understood as interest on equity. Both data are available in the companies' cash flow statements.

${ }^{30}$ Regarding the strategy of maximizing shareholder value in Brazil, Paula and Oreiro (2019) argue that there are not enough studies and empirical consistency to ensure that there is a consolidated phenomenon of MSV in Brazilian companies. It is worth mentioning that our sample is relatively small and the investigation of corporate practices linked to MSV should take into account a larger sample.

31 "So here we will cast the net widely and define financialization quite broadly: for us, financialization means the increasing role of financial motives, financial markets, financial actors and financial institutions in the operation of the domestic and international economies" (Epstein 2005, p. 3).
} 


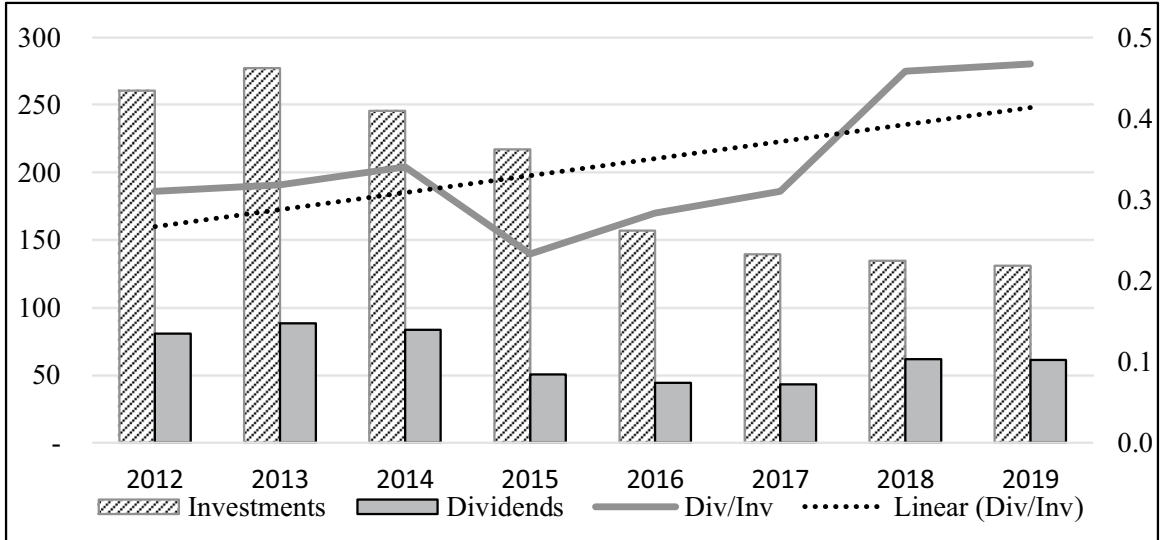

Graph 7 Fixed investment and dividends paid (in billions of R\$) and the share of dividends by investments: 2010-2019. Data source: authors own elaboration based on CVM database. Values updated by inflation at 2019 prices

strategy of the largest Brazilian non-financial firms during the 2015-2016 recession and period afterwards when macroeconomic policy was guided by austerity.

Our main conclusion is that, although the recession has contributed to weakening the balance sheets of the non-financial firms, as predicted by Minsky's theory of the endogenous cycle, it also contributed to the deepening of the financialization process at the firm level. The features of financialization identified regard to the decreasing investment in fixed assets and operating profit, while the financial income and dividends payment increased. This pattern of behavior distinguishes from the reported by Gottschalk and Torija-Zane (2017) during the great financial crisis, what is crucial to understand the different responses of the Brazilian economy when facing the recessions of 2008 and 2015-2016. Therefore, we understand that the recession of 2015-2016, combined with the adverse macroeconomic context, has deepened the financialization of non-financial companies which, in turn, inhibited the recovery of the Brazilian economy and the resumption of a positive economic cycle. Hence, the connection between the financialization process and the dynamics of the Minskyan cycle is presented as a crucial analytical element to help understand corporate practice in Brazil in recent years. Thereby, the analytical framework encompassed by this connection is not limited to analyze the Brazilian case, as it might accommodate the study of the economic cycles of further national economies for future research.

We also show that, in a financialized environment, large firms can sustain their cash flow through financial revenues, even at a low level of aggregate demand. In this regard, in a financially integrated economy in a context of fiscal austerity, as is the case of Brazil, business cycles tend to be more severe due to reduced policy space in recessions and the recovery slower.

The empirical analysis pointed to a defensive behavior on the part of the nonfinancial companies after the 2015-2016 recession in the way that they prioritized debt restructuring and the payment of dividends to shareholders while decreasing expenditures in fixed assets. The debt profile restructuring strategy after the 
2015-2016 recession was captured by the financial instability proxy, which showed that as of 2016, the number of companies that presented a hedge financial profile was increasing in our sample. However, the data analysis also indicated an increase in the companies' cash flow dependence on non-operating activities. Nonetheless, as previously pointed, this pattern of behavior may vary according to the companies' size and sector, which implies an open field for further research on this matter.

The empirical analysis further supports the interpretation that, even with the fall in interest rates, there was no recovery of confidence in expectations to resume investment in fixed capital. This can be seen in the debt "cleaning" movement, together with the increase in the volume of amortizations and the reduction of longterm liabilities since 2015. In 2019, the increase in the funding raised by non-financial companies, combined with the fall in investment, signaled a scenario where the decision to invest is deferred. In other words, from the sample of large non-financial companies, the Brazilian economy would never have "taken off" in 2019, as stated by the economic authorities. It is more reasonable to assume a scenario in which the state of expectations of the agents has not been restored after the 2015-2016 recession. The choice to reduce liabilities and restructure the debt profile to the detriment of productive investment, even with interest rates at historically low levels, corroborates the argument that agents' decisions do not only respond to supply-side conditions but rather are guided by expectations of future returns, which fundamentally depend on sustaining aggregate demand. In this scenario, the economic policy marked by fiscal austerity, a pattern observed in Brazil since 2015, prevented the resumption of economic growth, since investment is the key determinant of growth.

\section{Appendix}

Table 2

Table 2 Number of observations of the sample for each entry by year (2012 - 2019)

\begin{tabular}{lllllllll}
\hline Number of observations & 2012 & 2013 & 2014 & 2015 & 2016 & 2017 & 2018 & 2019 \\
\hline AFFI & 96 & 98 & 99 & 99 & 100 & 100 & 100 & 100 \\
Operating profit & 97 & 98 & 99 & 99 & 100 & 100 & 100 & 100 \\
Financial income & 96 & 97 & 98 & 99 & 100 & 100 & 100 & 100 \\
Amortization paid & 95 & 98 & 99 & 99 & 100 & 100 & 100 & 100 \\
Financial expenses & 96 & 98 & 99 & 99 & 100 & 100 & 100 & 100 \\
Tax & 96 & 98 & 99 & 99 & 100 & 100 & 100 & 100 \\
Loans of long-term liabilities & 94 & 98 & 99 & 99 & 100 & 100 & 100 & 100 \\
Loans of short-term liabilities & 94 & 98 & 99 & 99 & 100 & 100 & 100 & 100 \\
New loans and funding & 93 & 98 & 96 & 98 & 97 & 88 & 91 & 95 \\
Investments & 94 & 96 & 97 & 99 & 99 & 99 & 100 & 100 \\
Dividends paid & 81 & 84 & 84 & 84 & 85 & 82 & 85 & 85 \\
\hline
\end{tabular}




\section{Graph 8}

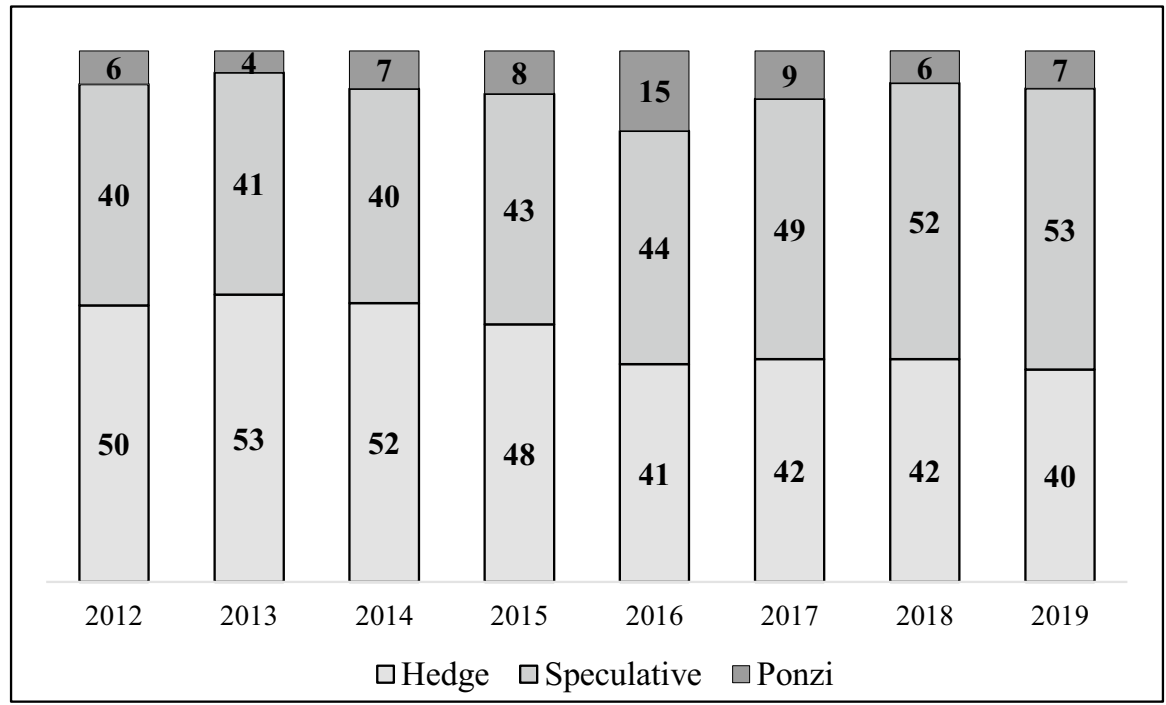

Graph 8 Distribution of non-financial companies by financial profile (2012-2019)

\section{References}

Aglietta M (2000) Shareholder value and corporate governance: some tricky questions. Econ Soc 29(1):146-159

Arestis P, Sawyer M (2005) Financial liberalization and the finance growth nexus: what have we learned? In: Arestis P, Sawyer M (eds) Financial Liberalization: Beyond Orthodox Concerns, Palgrave Macmillan

Arestis P, Glickman M (2002) Financial crisis in the South East Asia: dispelling illusion the Minskyan way. Camb J Econ 26(2):237-260

Barbosa-Filho NH (2010) Latin America: counter-cyclical policy in Brazil- 2008-2009. J Glob Dev 1(1):13, available at http://www.bepress.com/jgd/vol1/Iss1/art13

Caldentey EP, Negront NF, Lobos LM (2019) Corporate debt in Latin America and its macroeconomic implications. J Post Keynesian Econ 42(3):335-362

Carneiro R (2017) Navegando a contravento (Uma reflexão sobre o experimento desenvolvimentista do Governo Dilma Rousseff); Discussion Paper, Unicamp-IE, $n^{\circ} .289$

Carvalho L (2018) Valsa Brasileira: Do Boom ao Caos Econômico. Todavia, São Paulo

Davis LE (2016) Identifying the "financialization" of the nonfinancial corporation in the US economy: a decomposition of firm-level balance sheets. J Post Keynesian Econ 39(1):115-141

Davis LE, de Souza JPA, Hernandez G (2019) An empirical analysis of Minsky regimes in the US economy. Camb J Econ 43(3):541-583

Davis LE, McCormack S (2021) Industrial stagnation and the financialization of nonfinancial corporations. Rev Evol Polit Econ. https://doi.org/10.1007/s43253-021-00043-6

Epstein GA (2005) Financialization and the world economy. Edward Elgar Publishing

Feijo C, Lamônica MT, Bastos JCA (2016) Why does the investment rate not increase? Capital accumulation and stabilization policy in the 1990s and 2000s in Brazil. J Post Keynesian Econ 39(4):539

Feijo C, Lamônica MT, Lima SS (2020) Investment cycle of the Brazilian economy: a panel cointegration analysis of industrial firms based on Minsky's financial instability hypothesis - 20072017. J Post Keynesian Econ.https://doi.org/10.1080/01603477.2020.1840277 
Ferrari-Filho F, Cunha AM, Bichara JS (2014) Brazilian countercyclical economic policies as a response to the great recession: a critical analysis and an alternative proposal to ensure macroecomic stability. J Post Keynesian Econ 36(3):513-539

Fundação Getúlio Vargas (2020) Índice de Confiança Empresarial. Instituto Brasileiro de Economia, Rio de Janeiro, ed. fev.

Gottschalk R, Torija-Zane E (2017) Financialisation and investment behaviour among non-financial corporations in Brazil since the global crisis. In: Arestis P, Baltar CT, Prates DM (eds) The Brazilian economy since the great financial crisis of 2007/2008. Palgrave Macmillan

Guttmann R (2017) Financialization revisited: the rise and fall of finance-led capitalism. Economia e Sociedade 26(SPE):857-877

Hein E, Van Treeck T (2008) 'Financialisation' in post-Keynesian models of distribution and growtha systematic review. IMK working paper

Instituto de Estudos para o Desenvolvimento Industrial (2020) Carta n. 999. São Paulo. Available at: https://www.iedi.org.br/cartas/carta_iedi_n_999.html. Accessed Jun 162020

Karwowski E, Stockhammer E (2017) Financialisation in emerging economies: a systematic overview and comparison with Anglo-Saxon economies. Econ Polit Stud 5(1):60-86

Keynes JM (1936) The general theory of employment, interest and money. Palgrave Macmillan

Kohler K, Guschanski A, Stockhammer A (2019) The impact of financialization on the wage share: a theoretical clarification and empirical test. Post-Keynesian Economics Society, Working Paper 1802

Mader P, Mertens D, van der Zwan N (eds) (2020) The Routledge International Handbook on Financialization. Routledge.

Mazzucato M, Wray L (2015) Randall. Financing the capital development of the economy: a KeynesSchumpeter-Minsky synthesis. LEM Working Paper Series

Meyer R, de Paula LF (2021) Determinantes do Investimento Privado no Brasil em 2007-2017 a partir de uma perspectiva pós Keynesiana: uma análise empírica; Discussion Paper FINDE n. 13, March; available at: http://finde.uff.br/wp-content/uploads/sites/43/2021/03/td-19-final.pdf. Acessed May 262021

Minsky HP (1981) Inflation, recession, and economic policy (can "it" happen again? essays on instability and finance) Chapter 3: "The financial Instability Hypothesis: An interpretation of Keynes and an Alternative to Standard Theory". Armonk: M. E. Sharpe

Minsky HP (1986) Stabilizing an unstable economy. Yale University Press, New Haven

Minsky HP (1992) The financial instability hypothesis. The Jerome Levy Economics Institute Working Paper: no. 74

Minsky HP (1978) The financial instability hypothesis: a restatement ch 5. In: Minsky HP (ed) Can "it" happen again? Essays on instability and finance. ME Sharpe, New York, pp 90-116

Nassif A, Feijo C, Araújo E (2020) Macroeconomic policies in Brazil before and after the 2008 global financial crisis: Brazilian policy-makers still trapped in the new macroeconomic consensus guidelines. Camb J Econ. https://doi.org/10.1093/cje/beaa014

Nassif A, Castilho MR (2020) Trade patterns in a globalised world: Brazil as a case of regressive specialisation. Camb J Econ 44(3):671-701

Nikolaidi M, Stockhammer E (2017) Minsky models: a structured survey. J Econ Surv 31(5):1304-1331

Oreiro JL (2017) A grande recessão brasileira: diagnóstico e uma agenda de política econômica [The Brazilian great recession: diagnosis and a policy economic agenda]. Estudos Avançados 31(89):7588. https://doi.org/10.1590/s0103-40142017.31890009

Oreiro JL, D’Agostini L (2017) Macroeconomic policy regimes, real exchange rate overvaluation, and performance of the Brazilian economy (2003-2015). J Post Keynesian Econ 40:27-42

Orhangazi Ö (2008) Financialisation and capital accumulation in the non-financial corporate sector: A theoretical and empirical investigation on the US economy: 1973-2003. Camb J Econ 32(6):863-886

Palley T (2013) Financialization: the economics of finance capital domination. Palgrave Macmillan, New York

Paula LFde, Modenesi AdeM, Pires MCC (2015) The tale of the contagion of two crisis and policies responses in Brazil. J Post Keynesian Econ 37(3):408-435

Paula LF, Oreiro JL (2019) Macroeconomia da Estagnação [Macroeconomics of Stagnation]. Insight e Inteligência 87:90-99, out/nov/dez 
Pires M (2021) Investimentos Públicos: 1947-2020. Fiscal policy observatory, IBRE-FGV, Rio de Janeiro. Available at: https://observatorio-politica-fiscal.ibre.fgv.br/series-historicas/investimen tos-publicos/investimentos-publicos-1947-2020. Accessed Aug 232021

Serrano F, Summa R (2015) Aggregate demand and the slowdown of Brazilian economic growth in 2011-2014. Nova Economia 25:803-833

Stockhammer E (2004) Financialisation and the slowdown of accumulation. Camb J Econ 28:719-741

Stockhammer E (2007) Some stylized facts on the finance-dominated accumulation regime. Working Paper Series, Political Economy Research Institute, UMASS. n. 142

Torija-Zane E, Gottschalk R (2018) Patrones financieros y de inversión en América Latina desde la perspectiva del comportamiento empresarial. En: Abeles M, Caldentey EP, Valdecantos S (eds) Estudios sobre financierización en América Latina, Santiago, United Nations Publications

Torres-Filho ET, Martins NM, Miaguti CY (2019) Minsky's financial fragility: an empirical analysis of electricity distribution firms in Brazil (2007-2015). J Post Keynesian Econ 42(1):144-168

\section{Authors and Affiliations}

\section{Eduardo Mantoan ${ }^{1}\left(\mathbb{D} \cdot\right.$ Vinícius Centeno $^{1} \cdot$ Carmem Feijo $^{2,3} \cdot$ Financialization and Development Study Group (FINDE/UFF)}

Vinícius Centeno

vinicenteno@gmail.com

Carmem Feijo

cfeijo@id.uff.br

1 Federal University of Rio de Janeiro (UFRJ), Rio de Janeiro, Brazil

2 Fluminense Federal University (UFF), Niterói, Rio de Janeiro, Brazil

3 National Council for Scientific and Technological Development (CNPq), Rio de Janeiro, Brazil 